\title{
Az arányos csődszabály karakterizációja körbetartozások esetén
}

\begin{abstract}
Az arányos csődszabály első használata egészen Arisztotelészig vezethető vissza. A tanulmányban olyan pénzügyi hálózatokat vizsgálunk, ahol az ágenseknek van induló pénzkészlete, és mindenki tartozhat mindenkinek. Egy adott pénzügyi hálózatban a csődszabály meghatároz egy fizetési mátrixot, amelynek elemei megmondják, hogy ki mennyit fizessen a többi szereplőnek. Egy szereplö eszközei az induló pénzkészletéből és a többiektől kapott fizetésekből állnak. A rendszerkockázati irodalomban gyakran használt arányos csődszabály azt követeli meg, hogy az ágensek a tartozásaikkal arányosan fizessenek eszközeikből, maximum a tartozások erejéig. Ha érvényes az arányos csődszabály, akkor az eszközök értéke endogén módon határozódik meg, mivel a fizetések egymástól függhetnek. Cikkünkben részletesen bemutatjuk az arányos csődszabály egyik karakterizációját, olyan tulajdonságokat, amelyek közül mindegyiket csak ez a csődszabály teljesíti: a követelések felsőkorlát-jellegét, a korlátolt felelősséget, a hitelezők elsőbbségét, a pártatlanságot, az azonos ágensek általi manipulálhatatlanságot és a folytonosságot.* Journal of Economic Literature (JEL) kód: C71, G10.
\end{abstract}

\section{Bevezetés}

A csődjogban a követelésekkel arányos fizetés, az arányos csődszabály természetes módon adódik, és használata széles körben elterjedt (az amerikai csődjogra lásd például Kaminski [2000]), így fontos karakterizálni, megvizsgálni azokat a tulajdonságokat, amelyeket csak ez a csődszabály teljesít.

A sokat idézett O’Neill [1982] cikktől kezdődően a csődszabályokat matematikailag leíró elméleti irodalom csak egyetlenegy csődbe ment ágenssel foglalkozott, akinek a vagyonára vonatkozóan a többieknek követelése van. Ezt a problémát

* A szerző köszöni az NKFIH K109354. és K120035. számú kutatási projektjeinek a támogatását és a Magyar Közgazdaságtudományi Egyesület 2016-os konferenciáján kapott hozzászólásokat.

Csóka Péter, BCE Gazdálkodástudományi Kar, Befektetések és Vállalati Pénzügy Tanszék és MTA

KRTK KTI Játékelméleti Kutatócsoport, (e-mail: peter.csoka@uni-corvinus.hu).

A kézirat első változata 2017. május 12-én érkezett szerkesztőségünkbe.

DOI: http://dx.doi.org/10.18414/KSZ.2017.9.930 
csődproblémának hívják (magyarul lásd Habis [2012] - a szerző sztochasztikus csődproblémákat elemez), a központi kérdés pedig az, hogy hogyan osszuk fel a vagyont igazságosan, különböző elosztási szabályokat vizsgálva (bővebben lásd Thomson [2003], [2013] és [2015] összefoglaló tanulmányait).

Csődproblémák esetén az arányos elosztási szabályt karakterizálja például Young [1988], Moreno-Ternero [2006], Ju és szerzőtársai [2007] és Thomson [2016], olyan tulajdonságokkal, mint az öndualitás (self-duality), a vagyonnövelés vagy -csökkentés (composition up, composition down), manipulálhatatlanság (non-manipulability), valamint az összeolvadás- és szétválásbiztosság (merging-and splitting proofness). Kapcsolódó karakterizációkat használ Tasnádi [2002] véletlent is alkalmazó elosztási módszerekre, Moulin [2016] pedig különböző tulajdonságú javak arányos hozzárendelésére és elosztására.

A 2007-2008-as pénzügyi válság és az európai szuverén adósságválság óta a rendszerkockázati irodalom egyre inkább figyelembe veszi a csődök hálózatos és egymásra ható jellegét, visszanyúlva az Eisenberg-Noe [2001] tanulmányhoz, valamint az arányos csődszabályt használva a kölcsönös fizetések meghatározására. Az arányos csődszabályt használva

- kiterjesztették az alapmodellt (Cifuentes és szerzötársai [2005], Shin [2008], Rogers-Veraart [2013], Schuldenzucker és szerzötársai [2016]);

- elemezték a hálózatban lévő csődök számát és nagyságát (Lublóy [2005], GaiKapadia [2010], Berlinger és szerzőtársai [2011], Elliottés szerzőtársai [2014], Acemoglu és szerzötársai [2015], Capponi és szerzötársai [2015], Glasserman-Young [2015]); vagy

- mérték a rendszerkockázatot (Chen és szerzőtársai [2013], Demange [2017]).

A témáról jó áttekintést ad Glasserman-Young [2016].

A tanulmányban olyan pénzügyi hálózatokat vizsgálunk, ahol az ágenseknek van egy induló pénzkészlete, és mindenki tartozhat mindenkinek. Egy adott pénzügyi hálózatban a csődszabály egy fizetési mátrixot ad meg, amelynek elemei megmondják, hogy ki mennyit fizessen a többi szereplőnek. Egy szereplő eszközei az induló pénzkészletéből és a többiektől kapott fizetésekből állnak. Az arányos csődszabály azt követeli meg, hogy az ágensek maximum a tartozások erejéig a tartozásaikkal arányosan fizessenek eszközeikből. Az arányos csődszabály esetén az eszközök értéke endogén módon határozódik meg, mivel a fizetések egymástól függhetnek. Cikkünkben részletesen bemutatjuk az arányos csődszabály egyik karakterizációját, olyan tulajdonságokat, amelyek közül mindegyiket csak ez a csődszabály teljesíti: a követelések felsőkorlát-jellegét, a korlátolt felelősséget, a hitelezők elsőbbségét, a pártatlanságot, az azonos ágensek általi manipulálhatatlanságot és a folytonosságot.

\section{Jelölések, pénzügyi hálózatok}

Legyen $\mathbb{N}$ a lehetséges ágensek halmaza, és jelölje $\mathcal{N}$ a nem üres, véges részhalmazokat $\mathbb{N}$-ben.

Pénzügyi hálózatnak az $(N, z, L)$ hármast hívjuk. Az ágensek halmaza $N \in \mathcal{N}$. Azágensek induló készlete a $z \in \mathbb{Q}_{++}^{N}$, szigorúan pozitív racionális szám. A készletbe beletartozik 
minden tárgyi és immateriális eszköz, kivéve a többi ágensre vonatkozó követelést. A cikk nagy részében a gyakorlati példákat teljesen megragadó racionális esettel dolgozunk, de később az elméletileg érdekes racionális esetre is ki fogunk térni.

Az ágensek egymással szembeni követeléseit a nem negatív $L \in \mathbb{Q}_{+}^{N \times N}$ tartozási mátrix adja meg. A tartozási mátrix $L_{i j}$ eleme az $i$-edik ágens tartozása a $j$-edik ágensnek, vagy másképp fogalmazva: a j-edik ágens követelése az $i$-edikkel szemben. Természetesen feltehetjük, hogy $L_{i i}=0$. Elöfordulhat, hogy két ágens kölcsönösen tartozik egymásnak, vagyis egyszerre lehet $L_{i j}>0$ és $L_{j i}<0$. Adott $N$ ágenshalmaz esetén a föátlójukban nullákat, egyébként nem negatív racionális számokat tartalmazó mátrixokat jelölje $\mathcal{M}(N)$. Ezeknek a mátrixoknak az összes véges ágens esetén vett uniója legyen $\mathcal{M}=\cup_{N \in N} \mathcal{M}(N)$. Az $\mathcal{M}(N)$-en értelmezett parciális rendezés $(\leq)$ a szokásos módon definiált: tetszőleges $P, P^{\prime} \in \mathcal{M}(N)$ mátrixra $P \leq P^{\prime}$ pontosan akkor, ha $P_{i j} \leq P_{i j}^{\prime}$ minden $(i, j) \in N \times N$-re.

Egy $P \in \mathcal{M}(N)$ mátrix és $i \in N$ ágens esetén jelölje $P_{i} \in \mathbb{Q}^{N}$ a $P$ mátrix $i$-edik sorát. Két sorvektor, $P_{i}, P_{i}^{\prime} \in \mathbb{Q}^{N}$ esetén $P_{i}<P_{i}^{\prime}$, ha $P_{i j} \leq P_{i j}^{\prime}$ minden $j \in N$, és létezik olyan $k \in N$, hogy $P_{i k}<P_{i k}^{\prime}$. Egy $P$ mátrix $i$-edik oszlopát jelölje $P^{i}$, az összes pénzügyi hálózat halmazát pedig $\mathcal{F}$.

Tekintsük az $(N, z, L) \in \mathcal{F}$ pénzügyi hálózatot! A $P \in \mathcal{M}(N)$ fizetési mátrix megadja az ágensek közötti fizetéseket, vagyis $P_{i j}$ az $i \in N$ ágens által a $j \in N$ ágensnek fizetett összeg. Egy $P \in \mathcal{M}(N)$ fizetési mátrix esetén az $i \in N$ ágens eszközeinek értéke legyen $a_{i}(N, z, P)$, ahol

$a_{i}(N, z, P)=z_{i}+\sum_{j \in N} P_{j i}$.

Az eszközök értékéből kivonva az ágens által fizetett összeget, megkapjuk az ágens saját tökéjét. Az $i \in N$ ágens saját tőkéje legyen $e_{i}(N, z, P)$, ahol

$e_{i}(N, z, P)=a_{i}(N, z, P)-\sum_{j \in N} P_{i j}=z_{i}+\sum_{j \in N}\left(P_{j i}-P_{i j}\right)$.

Könnyen látható, hogy a saját tőkét összeadva az összes ágensre, éppen az induló készletek összegét kapjuk, vagyis a fizetések csak átrendezik az induló készleteket.

A csődszabályok egy $(N, z, L) \in \mathcal{F}$ pénzügyi hálózathoz egy $P \in \mathcal{M}(N)$ fizetési mátrixot rendelnek.

1. DEFiníció - A csődszabály egy olyan $b: \mathcal{F} \rightarrow \mathcal{M}$ függvény, amelynél minden $(N, z, L) \in \mathcal{F}$-re b $(N, z, L) \in \mathcal{M}(N)$.

A pénzügyi hálózatok elemzése azért bonyolult, mert körbetartozások lehetnek, és a csőd fertőzéssel terjedhet. Sokkal egyszerübb a sokat elemzett csődproblémák családja (magyarul lásd Habis [2012] - a szerző sztochasztikus csődproblémákat elemez). A csődproblémákban egy $E \in \mathbb{Q}_{+}$nagyságú vagyont kell felosztani az $N \in \mathcal{N}$ halmazban lévő hitelezők között, akiknek a követelésvektora $c \in \mathbb{Q}^{N}$. Csődproblémák esetén elosztási szabályokat fogunk használni. A $d^{\mathrm{a}}: \mathbb{Q}_{+} \times \mathbb{Q}_{+}^{N} \rightarrow \mathbb{Q}_{+}^{N}$ arányos elosztási szabály a $j \in N$ hitelezöhöz a $d_{j}^{a}(E, c)$ összeget rendeli, ahol 
$d_{j}^{\mathrm{a}}(E, c)=\left\{\min \left\{\frac{c_{j}}{\sum_{k \in N} c_{k}} E, c_{j}\right\} \quad\right.$ egyébként.

Az arányos elosztási szabály esetén a vagyont a követelések arányában osztják fel, azzal a megkötéssel, hogy senki sem kaphat többet, mint a követelése.

Pénzügyi hálózatok esetén a $p: \mathcal{F} \rightarrow \mathcal{M}$ arányos csődszabály az ágensek vagyonaként eszközeik értékét tekinti, majd az arányos elosztási szabállyal elosztja ezt az eszközértéket a tartozásokkal arányosan.

2. Definíció • A $p: \mathcal{F} \rightarrow \mathcal{M}$ függvény arányos csődszabály, ha minden $(N, z, L) \in \mathcal{F}$ hálózathoz a $p(N, z, L)=P$ mátrixot rendeli, ahol $P$ az (1) egyenletrendszer megoldása:

$P_{i j}=d_{j}^{\mathrm{a}}\left[a_{i}(N, z, P), L_{i}\right], \quad i, j \in N$.

Az (1) egyenletben az $i$-edik ágenst úgy kell kezelni, mint akinek a saját $a_{i}(N, z, P)$ vagyonára vonatkozóan nincs követelése $\left(L_{i i}=0\right)$, így önmagának nem fog fizetni semmit. Használva $d_{j}^{\mathrm{a}}\left[a_{i}(N, z, P), L_{i}\right]$ definícióját, megadhatjuk az (1) egyenletrendszert úgy, hogy minden $i, j \in N$ esetén

$P_{i j}= \begin{cases}0, & \text { ha } L_{i j}=0, \\ \min \left\{\frac{L_{i j}}{\sum_{k \in N} L_{i k}} a_{i}(N, z, P), L_{i j}\right\} & \text { egyébként. }\end{cases}$

Felhasználva Eisenberg-Noe [2001] eredményeit, Csóka-Herings [2017] belátja, hogy a (2) egyenletrendszernek csak egy megoldása van, és az racionális számokat tartalmaz, így a $p$ arányos csődszabály jól definiált.

$\mathrm{Az}$ arányos csődszabály egyik lehetséges kiterjesztése az, ha előbb az ágensek páronként nettósítanak, majd az így kapott tartozási mátrixra (ahol minden $i, j \in N$ ágensre fennáll, hogy vagy $L_{i j}=0$, vagy $L_{j i}=0$ ) alkalmazzák az arányos csődszabályt.

3. DEFiníció • A pna: $\mathcal{F} \rightarrow \mathcal{M}$ páronként nettósító arányos csődszabály olyan függvény, amely minden $(N, z, L) \in \mathcal{F}$ hálózathoz a $p n a(N, z, L)$ fizetési mátrixot rendeli, ahol

$\operatorname{pna}(N, z, L)=\min \left\{L, L^{\mathrm{T}}\right\}+p\left(N, z, L-\min \left\{L, L^{\mathrm{T}}\right\}\right)$.

A páronként nettósító arányos csődszabály esetén tehát először a páronként nettósító fizetések történnek meg, majd a maradék tartozásokra alkalmazzák az arányos csődszabályt. Könnyen látható, hogy a páronként nettósító arányos csődszabály, a pna is az $\mathcal{M}(N)$-beli racionális számokat tartalmazó fizetési mátrixokra vezet. 
Az 1. PÉLDÁBAN illusztráljuk az arányos csődszabályt és a páronként nettósító arányos csődszabályt, és megmutatjuk, hogy eltérő eszközökre és sajáttőke-értékekre vezethetnek.

1. PÉLDA • Tekintsük az $(N, z, L) \in \mathcal{F}$ pénzügyi hálózatot három ágenssel $(N=\{1,2,3\})$ és az 1. táblázatban lévő készletekkel és tartozásokkal. A 2. táblázatban láthatjuk azt a $P$ fizetési mátrixot, amely a $p$ arányos csődszabályhoz tartozik, a kapcsolódó eszközök és a saját tőkék értékeit. A 3. táblázatban vannak a $\min \left\{L, L^{\mathrm{T}}\right\}$ páronkénti nettósításból származó fizetések, a maradék tartozásokra az arányos csődszabályt alkalmazva a $P^{\prime}=p\left(N, z, L-\min \left\{L, L^{\mathrm{T}}\right\}\right)$ fizetési mátrix, valamint a pna páronként nettósító arányos csődszabályhoz tartozó $\bar{P}$ fizetési mátrix, az eredő $a(\bar{P})$ eszközök és $e(\bar{P})$ sajáttőke-értékek.

\section{1. táblázat}

Az 1. PÉLDÁBAN lévő készletek és tartozások

\begin{tabular}{c|ccc}
$z$ & \multicolumn{3}{|c}{$L$} \\
\hline 12 & 0 & 12 & 12 \\
6 & 6 & 0 & 0 \\
6 & 0 & 0 & 0
\end{tabular}

\section{2. táblázat}

A $p$ arányos csődszabályból eredő fizetési mátrix, eszköz- és sajáttőke-értékek az 1. PÉLDÁBAN

\begin{tabular}{c|ccc||ccc|c|c}
$z$ & \multicolumn{3}{|c|}{$L$} & & $P$ & & $a(N, z, P)$ & $e(N, z, P)$ \\
\hline 12 & 0 & 12 & 12 & 0 & 9 & 9 & 18 & 0 \\
6 & 6 & 0 & 0 & 6 & 0 & 0 & 15 & 9 \\
6 & 0 & 0 & 0 & 0 & 0 & 0 & 15 & 15
\end{tabular}

\section{3. táblázat}

A páronként nettósító arányos csődszabályból eredő fizetési mátrix $(\bar{P})$, eszköz- és sajáttőke-értékek az 1. PÉLDÁBAN

\begin{tabular}{c|cc|cc||cc||ccc|ccc|ccc|c|c|c|}
$z$ & \multicolumn{3}{|c|}{$L$} & \multicolumn{3}{|c|}{$L^{\prime}$} & $\min \left\{L, L^{\mathrm{T}}\right\}$ & & $P^{\prime}$ & & $\bar{P}$ & $a(\bar{P})$ & $e(\bar{P})$ \\
\hline 12 & 0 & 12 & 12 & 0 & 6 & 12 & 0 & 6 & 0 & 0 & 4 & 8 & 0 & 10 & 8 & 18 & 0 \\
6 & 6 & 0 & 0 & 0 & 0 & 0 & 6 & 0 & 0 & 0 & 0 & 0 & 6 & 0 & 0 & 16 & 10 \\
6 & 0 & 0 & 0 & 0 & 0 & 0 & 0 & 0 & 0 & 0 & 0 & 0 & 0 & 0 & 0 & 14 & 14
\end{tabular}

$L^{\prime}=L-\min \left\{L, L^{\mathrm{T}}\right\}$,

$P^{\prime}=p\left(N, z, L-\min \left\{L, L^{\mathrm{T}}\right\}\right)$.

Azt látjuk, hogy a $P$ és $\bar{P}$ fizetési mátrixok különböző sajáttőke-értékeket adnak a 2-es és a 3-as ágenseknek. Az eltérés oka az, hogy az 1-es és 2-es ágens közötti páronkénti nettósítás ekvivalens azzal, hogy az 1-es ágens tartozásainak felét teljes egészében megfizeti a 2-es ágensnek. A 1-es ágens maradék tartozásaira az arányos csődszabályt 
alkalmazzuk. Összességében jobban jár a 2-es ágens, mint ha az 1-es ágens teljes tartozására alkalmaznánk az arányos csődszabályt. Ebben a példában a páronként nettósító arányos csődszabálynak az a rossz tulajdonsága, hogy az 1-es ágens 10-et fizet a 2-es ágensnek és 8-at a 3-asnak, pedig azonos összegekkel tartozik nekik.

\section{Az arányos csődszabály tulajdonságai}

Ebben részben definiáljuk és illusztráljuk az arányos csődszabályt karakterizáló tulajdonságokat, amelyeket két csoportra bontunk. Az első csoportba tartoznak az összes csődszabálytól megkövetelhető tulajdonságok: a követelések mint felső korlát, a korlátolt felelösség, a hitelezők elsőbbsége. A második csoportban is természetesen megkövetelhető tulajdonságok vannak, de ezeket már nem minden csődszabály teljesíti: a pártatlanság, az azonos ágensek általi manipulálhatatlanság és a folytonosság.

4. DEFiníció $\bullet$ A $b: \mathcal{F} \rightarrow \mathcal{M}$ csődszabály teljesíti a követelések felsőkorlát-tulajdonságát, ha minden $F=(N, z, L) \in \mathcal{F}$ pénzügyi hálózat esetén $b(F) \leq L$.

A követelések felsőkorlát-tulajdonsága azt jelenti, hogy mindegyik ágens mindenkinek maximum a vele szemben fennálló követelést fizesse. Többet fizetni vagy egyébként sem kívánnak a szereplök, vagy nem törvényes esetleg így menekíteni a vagyont.

5. DEFINíció • A b: $\mathcal{F} \rightarrow \mathcal{M}$ csődszabály teljesíti a korlátoltfelelősség-tulajdonságot, ha minden $F=(N, z, L) \in \mathcal{F}$ pénzügyi hálózat és minden $i \in N$ ágens esetén $e_{i}[N, z, b(F)] \geq 0$.

Egy csődszabály akkor teljesíti a korlátoltfelelősség-tulajdonságot, ha olyan fizetési mátrixot eredményez, amelyben egyik ágensnek sem negatív a saját tőkéje. Egyébként a korlátlan felelősség is megragadható a modellel, ha a készletbe belevesszük azokat a javakat, amelyeket a korlátlan felelősség miatt esetleg még elvehetnek az adott ágenstöl.

6. DEFINíció $\bullet \mathrm{A} b: \mathcal{F} \rightarrow \mathcal{M}$ csődszabály teljesíti a hitelezők elsőbbsége tulajdonságát, ha minden $F=(N, z, L) \in \mathcal{F}$ pénzügyi hálózatra, minden $i \in N$ ágensre ha $b_{i}(F)<L_{i}$, akkor $e_{i}[N, z, b(F)]=0$.

A hitelezők elsőbbsége tulajdonság azt jelenti, hogy ha valamelyik ágens nem fizeti ki az összes tartozását, akkor annak a hitelezőnek a saját tőkéje legyen nulla. Másképpen fogalmazva, csak akkor maradhat pozitív egy ágens saját tökéje, ha minden tartozását kifizette.

7. DEFINíció - A b: $\mathcal{F} \rightarrow \mathcal{M}$ csődszabály teljesíti a pártatlanság tulajdonságát, ha minden $F=(N, z, L) \in \mathcal{F}$ pénzügyi hálózatra, minden $i, j, k \in N$ ágensre ha $L_{i j}=L_{i k}$, akkor $b_{i j}(F)=b_{i k}(F)$. 
A pártatlanság azt követeli meg, hogy ha a $j$ és a $k$ ágens ugyanannyit követel az $i$ ágenstől, akkor ugyanannyit is kapjanak tőle. Láttuk az 1. PÉLDÁBAN, hogy a pártatlanság nem teljesül a páronként nettósító arányos csődszabályra.

Csődproblémák esetén a manipulálhatatlanság azt jelenti, hogy az ágensek egyetlen csoportja sem tudja növelni az összesen rájuk osztott vagyont a követeléseik összevonásával, és senki sem tudja úgy növelni a ráosztott vagyont, hogy követelését feldarabolja. Ezt az axiómát O’Neill [1982] vezette be csalásbiztosság (strategy-proofness) néven. Az erős manipulálhatatlanság, amit Curiel és szerzőtársai [1987] követelések additivitása (additivity of claims) néven vezetett be, azt írja elö, hogy a követelések összevonásával vagy feldarabolásával a nem érintett ágensek kifizetése nem változik (és így az érintetteké sem).

Hálózatok esetén az erős manipulálhatatlanság definiálásához legyen adott az $F=(N, z, L) \in \mathcal{F}$ pénzügyi hálózat, a $j \in N$ ágens és a rajta kívül lévő $K \subset N \backslash\{j\}$ ágensek halmaza. Legyen $F^{\prime}=\left(N^{\prime}, z^{\prime}, L^{\prime}\right)$ az a $T=(F, j, K)$-val jelölt pénzügyi hálózat, amely úgy keletkezik, hogy a $j$ ágens összeolvad a $K \subset N \backslash\{j\}$ halmazban lévő ágensekkel a készletek, követelések és tartozások terén, vagyis

$$
\begin{aligned}
& N^{\prime}=N / K, \\
& z_{j}^{\prime}=z_{j}+\sum_{k \in K} z_{k}, \\
& z_{i}^{\prime}=\quad z_{i}, \quad i \in N^{\prime} \backslash\{j\}, \\
& L_{j i}{ }^{\prime}=L_{j i}+\sum_{k \in K} L_{k i}, \quad i \in N^{\prime} \backslash\{j\} \text {, } \\
& L_{i j}^{\prime}=L_{i j}+\sum_{k \in K} L_{i k}, \quad i \in N^{\prime} \backslash\{j\}, \\
& L_{h i}{ }^{\prime}=\quad L_{h i}, \quad h, i \in N^{\prime} \backslash\{j\} .
\end{aligned}
$$

A manipulálhatatlanság definíciója Csóka-Herings [2017] alapján a következő.

8. DEFINíció • A b: $\mathcal{F} \rightarrow \mathcal{M}$ csődszabály teljesíti a manipulálhatatlanság tulajdonságát, ha minden $F=(N, z, L) \in \mathcal{F}$ pénzügyi hálózat, minden $j \in N$ ágens és minden $K \subset N \backslash\{j\}$ ágenshalmaz esetén az $F^{\prime}=\left(N^{\prime}, z^{\prime}, L^{\prime}\right)=T(F, j, K)$ pénzügyi hálózatban lévő fizetésekre igaz, hogy

$$
\begin{aligned}
& b_{j i}\left(F^{\prime}\right)=b_{j i}(F)+\sum_{k \in K} b_{k i}(F), \quad i \in N^{\prime} \backslash\{j\}, \\
& b_{i j}\left(F^{\prime}\right)=b_{i j}(F)+\sum_{k \in K} b_{i k}(F), \quad i \in N^{\prime} \backslash\{j\}, \\
& b_{h i}\left(F^{\prime}\right)=\quad b_{h i}(F), \quad h, i \in N^{\prime} \backslash\{j\} .
\end{aligned}
$$

A manipulálhatatlanság szerint az ágensek összeolvadása összességében nem változtatja meg az összeolvadásban nem érintett ágensekhez befolyó vagy tőlük kifolyó kifizetéseket. Alulról felfelé olvasva az egyenleteket, azok úgy is értelmezhetők, hogy 
egy ágens szétválása több ágensre nem befolyásolja a szétválásban nem érintett ágensekhez befolyó vagy tölük kifolyó kifizetéseket.

Úgy is értelmezhetjük a definíció első két egyenletsorát, hogy manipulálhatatlan csődszabály esetén az érintett ágensek összeolvadással nem járnak jobban, mert maximum ugyanannyit fizetnek, és legalább ugyanannyit kapnak:

$b_{j i}\left(F^{\prime}\right) \leq b_{j i}(F)+\sum_{k \in K} b_{k i}(F), \quad i \in N^{\prime} \backslash\{j\}$,

$b_{i j}\left(F^{\prime}\right) \geq b_{i j}(F)+\sum_{k \in K} b_{i k}(F), \quad i \in N^{\prime} \backslash\{j\}$.

Valamint az érintett ágensek szétválással sem járnak jobban, mert maximum ugyanannyit fizetnek, és legalább ugyanannyit kapnak:

$b_{j i}\left(F^{\prime}\right) \geq b_{j i}(F)+\sum_{k \in K} b_{k i}(F), \quad i \in N^{\prime} \backslash\{j\}$,

$b_{i j}\left(F^{\prime}\right) \leq b_{i j}(F)+\sum_{k \in K} b_{i k}(F), \quad i \in N^{\prime} \backslash\{j\}$,

és az így kapott egyenlőtlenségek vezetnek a definícióbeli egyenlőségekhez.

Különösen robusztussá teszi a manipulálhatatlanságot az, hogy a harmadik egyenletsor szerint a nem érintett ágensek közötti kifizetések sem változhatnak, mivel nem ad lehetőséget arra, hogy az összeolvadásban vagy szétválásban nem érintett, de azzal jól járó ágensek egymást kompenzálják.

Összefoglalva, a manipulálhatatlanság azt követeli meg, hogy az ágensek összeolvadása vagy szétválása összességében ne befolyásolja a fizetési mátrixot.

Bár természetesnek tűnik, de a manipulálhatatlanság túl erős követelmény pénzügyi hálózatok esetén. Először belátjuk, hogy az arányos csődszabály nem teljesíti.

2. PÉLDA • Tekintsük újra az 1. PÉLDÁBAN található $F=(N, z, L) \in \mathcal{F}$ pénzügyi hálózatot. Tegyük fel, hogy az 1-es ágens szétválik, és így egy 4-es ágens is keletkezik az $F^{\prime}=\left(N^{\prime}, z^{\prime}, L^{\prime}\right)=\left(N \cup\{4\}, z^{\prime}, L^{\prime}\right)$ pénzügyi hálózatban. A szétválás során az 1-es ágens készleteinek felét és összes tartozását a 4-es ágensnek adja, de az összes követelését megtartja. A 4. táblázatban látható az $F^{\prime}$ pénzügyi hálózat, valamint az arányos csődszabályból eredő $P^{\prime}$ fizetési mátrix is. Vegyük észre, hogy $F=T\left(F^{\prime}, 1,\{4\}\right)$.

\section{4. táblázat}

A arányos csődszabály által generált fizetési mátrix, eszköz- és sajáttőke-értékek a 2. PÉLDA $F^{\prime}=\left(N^{\prime}, z^{\prime}, L^{\prime}\right)$ pénzügyi hálózatában

\begin{tabular}{|c|c|c|c|c|c|c|c|c|c|c|}
\hline$z^{\prime}$ & \multicolumn{4}{|c|}{$L$} & \multicolumn{4}{|c|}{$P^{\prime}$} & $a\left(N^{\prime}, z^{\prime}, P^{\prime}\right)$ & $e\left(N^{\prime}, z^{\prime}, P^{\prime}\right)$ \\
\hline 6 & 0 & 0 & 0 & 0 & 0 & 0 & 0 & 0 & 12 & 12 \\
\hline 6 & 6 & 0 & 0 & 0 & 6 & 0 & 0 & 0 & 9 & 3 \\
\hline 6 & 0 & 0 & 0 & 0 & 0 & 0 & 0 & 0 & 9 & 9 \\
\hline 6 & 0 & 12 & 12 & 0 & 0 & 3 & 3 & 0 & 6 & 0 \\
\hline
\end{tabular}


Az arányos csődszabály manipulálható, mert $P_{12}=9 \neq 3=P_{12}^{\prime}+P_{42}^{\prime}$ és $P_{13}=9 \neq 3=$ $=P_{13}^{\prime}+P_{43}^{\prime}$, a fizetési mátrix összességében változott. A 4-es ágensnek nincs követelése, és a tartozása meghaladja a készletét, így biztosan csődbe fog menni. Ugyanakkor az 1-es ágensnek nincs tartozása, pozitív a készlete és a követelése is, úgyhogy biztosan szolvens lesz. Az 1-es ágens, aki csődbe ment az eredeti $F$ pénzügyi hálózatban, és akire $e_{1}[N, z, p(F)]=0$ volt, szétvált a szolvens új 1-es ágensre és a csödös 4-es ágensre az $F^{\prime}$ pénzügyi hálózatban, így a saját tőkéje $e_{1}\left[N^{\prime}, z^{\prime}, p\left(F^{\prime}\right)\right]=12$ és $e_{4}\left[N^{\prime}, z^{\prime}, p\left(F^{\prime}\right)\right]=0$ lett. Természetesen, ha egy csődös ágens szétválhat úgy, hogy az egyik résznek csak követelései vannak, a tartozásokat pedig csak a másik rész örökli, akkor az első résznek pozitív lesz a saját tőkéje, a másik pedig csődbe megy. Az ilyen manipulálás illegális, mivel a csődeljárás vagy felszámolási eljárás során az adós nem tehet olyat, ami közvetlenül vagy közvetve veszélyezteti a hitelezői követelések kielégítését (lásd például 1346/2000/EK-tanácsrendelet, többször módosítva).

Csóka-Herings [2017] a 2. PÉLDA alapján belátta az 1. (LEHETETLENSÉGI) TÉTELT.

1. TÉT EL • Nincs olyan csődszabály, amely egyszerre teljesíti a követelések mintfelső korlát, korlátolt felelösség, hitelezők elsőbbsége és manipulálhatatlanság tulajdonságokat.

A manipulálhatatlanság tulajdonság tehát valóban túl erős, így Csóka-Herings [2017] az azonos ágensek általi manipulálhatatlanságra gyengíti, ami szerint az azonos készlettel, követeléssel és tartozásokkal rendelkező ágensek összeolvadása vagy szétválása összességében nem befolyásolja a fizetési mátrixot. Ezt a megállapítást a 9. DEFINíció formálisan is leírja.

9. DEFINíció • A $b: \mathcal{F} \rightarrow \mathcal{M}$ csődszabály teljesíti az azonos ágensek általi manipulálhatatlanság tulajdonságot, ha minden $F=(N, z, L) \in \mathcal{F}$ pénzügyi hálózat, minden $j \in N$ ágens és minden $K \subset N \backslash\{j\}$ ágenshalmaz esetén, ahol minden $k \in K$-ra $z_{k}=z_{j}$, $L_{k}=L_{j} e ́ s L^{k}=L^{j}$, az $F^{\prime}=\left(N^{\prime}, z^{\prime}, L^{\prime}\right)=T(F, j, K)$ pénzügyi hálózatban lévő fizetésekre igaz, hogy

$$
\begin{array}{rlrl}
b_{j i}\left(F^{\prime}\right)= & b_{j i}(F)+\sum_{k \in K} b_{k i}(F), & & i \in N^{\prime} \backslash\{j\}, \\
b_{i j}\left(F^{\prime}\right)= & b_{i j}(F)+\sum_{k \in K} b_{i k}(F), & & i \in N^{\prime} \backslash\{j\}, \\
b_{h i}\left(F^{\prime}\right)= & b_{h i}(F), & h, i \in N^{\prime} \backslash\{j\} .
\end{array}
$$

Az azonos ágensek általi manipulálhatatlanságban minden $k \in K$-beli ágens azonos a $j$ ágenssel, vagyis azonos készlettel, követeléssel és tartozással rendelkezik. Mivel $L_{j j}=0$ és $L_{k k}=0$, az $L_{j}=L_{k}$ egyenlöségből az következik, hogy $L_{j k}=L_{k j}=0$, ami úgy általánosítható, hogy a $K$-beli azonos ágensek között nincsenek tartozások.

Hasonlóan a manipulálhatatlansághoz, itt is értelmezhetjük az első két egyenletsort úgy, hogy az azonos ágensek szétválással vagy összeolvadással nem járhatnak jobban. A harmadik sor itt is azt követeli meg, hogy a szétválásban vagy összeolvadásban nem érintett ágensek közötti kifizetések se változzanak. 
Összefoglalva, az azonos ágensek általi manipulálhatatlanság azt követeli meg, hogy az azonos ágensek összeolvadása vagy szétválása összességében ne befolyásolja a fizetési mátrixot.

Csóka-Herings [2017] a 2. TÉTELLEL karakterizálja az arányos csődszabályt a racionális számok esetére.

2. TÉTEL • A racionális számok esetén a p arányos csődszabály az egyetlen olyan csődszabály, amely teljesíti a követelések mint felső korlát, a korlátolt felelösség, a hitelezök elsőbbsége, a pártatlanság és az azonos ágensek általi manipulálhatatlanság tulajdonságokat.

A tétel értelmében az arányos csődszabály teljesíti a tulajdonságokat, és ha egy csődszabály teljesíti ezeket a tulajdonságokat, akkor az csak az arányos csődszabály lehet.

A valós számok esetén Csóka-Herings [2017] belátja, hogy a tulajdonságok sora a folytonossággal bővül (3. TÉTEL).

3. TÉTEL • A valós számok esetén a p arányos csödszabály az egyetlen olyan csödszabály, amely teljesíti a követelések mint felsö korlát, a korlátolt felelösség, a hitelezök elsőbbsége, a pártatlanság, az azonos ágensek általi manipulálhatatlanság és a folytonosság tulajdonságokat.

Csóka-Herings [2017] azt is igazolja, hogy a tulajdonságok függetlenek, vagyis mutat olyan csődszabályokat, amelyek egy kivételével az arányos csődszabálytól megkövetelt összes tulajdonságot teljesítik.

\section{Záró megjegyzések}

A gyakorlatban a csődproblémák gyakran összefüggenek, egy szereplő csődje hálózatszerüen továbbterjedhet, és körkörös hatásokat is okozhat. Így a felosztandó vagyon endogén módon határozódik meg, ami az axiomatikus karakterizációt különösen megnehezíti. Engle [2012] történeti visszatekintésében bemutatja, hogy a gyakorlatban gyakran és szinte világszerte használták az arányos csődszabályt. A rendszerkockázathoz kapcsolódó elméleti cikkekben is szinte kivétel nélkül ezt alkalmazzák. A cikkben erre az arányos csődszabályra elemeztünk egy egyszerü és természetesen elvárható tulajdonságokon alapuló karakterizációt. További kutatási irányként lehet keresni más karakterizációkat az arányos csődszabályra, illetve lehet elemezni más csődszabályokat is, valamint a tulajdonságok elemzése ígéretes a kísérleti közgazdaságtan segítségével is.

A csődproblémákban használt arányos elosztási szabály hálózatokra történő kiterjesztéséhez hasonlóan tetszőleges elosztási szabály alkalmazható. A kapott csődszabályokban kiszámítjuk az ágensek eszközeit, majd azokból az adott (akár ágensspecifikus) elosztási szabály szerint fizetünk. Természetesen elöfordulhat, hogy közben bizonyos ágensek eszközeinek értéke nő, így frissíteni kell a fizetési mátrixot. Végső soron egy fix pontot kell meghatároznunk, ezt a fix pontot 
Csóka-Herings [2018] klíringmátrixnak hívja. Ha minden ágens az arányos elosztási szabályt használja, akkor a klíringmátrix egyértelmü, de más elosztási szabályok esetén lehet több klíringmátrix is.

Továbbá a diszkrét esetben (amikor minden készlet, tartozás és követelés valamilyen elszámolási egységben mérhető) Csóka-Herings [2018] decentralizált klíringelő folyamatokat elemez, és megmutatja, hogy mindegyik véges lépésben konvergál a legkisebb klíringmátrixhoz, és ha az elszámolási egység kellően kicsi (például a pénzügyi hálózatok esetén), akkor mindegyik lényegében ugyanahhoz a saját tőkéhez vezet, mint ha központilag klíringelnénk.

Végül megemlítjük, hogy Groote Schaarsberg és szerzőtársai [2013] szintén pénzügyi hálózatokat vizsgál, de nem a kifizetéseket, hanem a saját tőkét elemzi. A szerzők belátják, hogy az elosztási szabályokon alapuló csődszabályokat használva a saját tőke nagysága minden ágensre egyértelmü, és karakterizálják az úgynevezett Aumann-Maschler-féle elosztási szabályon alapuló csődszabályt. Ugyanakkor nem minden csődszabály alapul elosztási szabályon. Például ha az ágensek előbb páronként nettósítanak, majd utána alkalmazzák az arányos csődszabályt, akkor az így kapott csődszabály nem tartozik ebbe az osztályba, mert a kifizetések nemcsak az eszközöktől és a tartozásoktól függ, hanem attól is, hogy mekkora a követelések nagysága. Az általunk elemzett karakterizáció nem feltételez semmilyen előzetes struktúrát, így a páronkénti nettósítás hiánya nem feltevés, hanem az elemzett tulajdonságok következménye.

\section{Hivatkozások}

Acemoglu, D.-Ozdaglar, A.-Tahbaz-Salehi, A. [2015]: Systemic Risk and Stability in Financial Networks. American Economic Review, Vol. 105. 564-608. o. https://doi. org/10.3386/w18727.

Berlinger Edina-Michaletzky Márton-Szenes Márk [2011]: A fedezetlen bankközi forintpiac hálózati dinamikájának vizsgálata a likviditási válság előtt és után. Közgazdasági Szemle, 58. évf. 3. sz. 229-252. o.

CApponi, A.-Chen, P.-C.-YAo, D. D. [2015]: Liability Concentration and Systemic Losses in Financial Networks. Megjelenés alatt, Operations Research, https://doi.org/10.1287/ opre.2015.1402.

Chen, C.-Iyengar, G.-Moallemi, C. C. [2013]: An Axiomatic Approach to Systemic Risk. Management Science, Vol. 59. 1373-1388. o. https://doi.org/10.1287/mnsc.1120.1631.

Cifuentes, R.-Ferrucci, G.-Shin, H. S. [2005]: Liquidity Risk and Contagion. Journal of the European Economic Association, Vol. 3. 556-566. o. https://doi.org/10.2139/ssrn.824166.

Curiel, I.-Maschler, M.-Tijs, S. H. [1987]: Bankruptcy Games. Mathematical Methods of Operations Research, Vol. 31. 143-159. o.

CsóKa PÉTer-Herings, P. J. J. [2017]: An axiomatization of the proportional rule in financial networks. Mühelytanulmány, SSRN Electronic Journal, https://doi.org/10.2139/ ssrn.2902653.

CsóKa PÉTer-Herings, P. J. J. [2018]: Decentralized Clearing in Financial Networks. Megjelenés alatt, Management Science. 
Demange, G. [2017]: Contagion in Financial Networks: A Threat Index. Megjelenés alatt, Management Science, https://doi.org/10.1287/mnsc.2016.2592.

EisenberG, L.-Noe, T. H. [2001]: Systemic Risk in Financial Systems. Management Science, Vol. 47. 236-249. o. https://doi.org/10.1287/mnsc.47.2.236.9835.

Elliott, M.-Golub, B.-Jackson, M. O. [2014]: Financial Networks and Contagion. American Economic Review, Vol. 104. No. 10. 3115-3153. o. https://doi.org/10.1257/ aer.104.10.3115.

Engle, E. [2012]: The History of the General Principle of Proportionality: An Overview. Dartmouth Law Journal, Vol. 10. 1-11. o.

Gai, P.-Kapadia, S. [2010]: Contagion in Financial Networks. Proceedings of the Royal Society of London A: Mathematical, Physical and Engineering Sciences, Vol. 466. No. 2120. 2401-2423. o. https://doi.org/10.1098/rspa.2009.0410.

Glasserman, P.-Young, H. P. [2015]: How Likely Is Contagion in Financial Networks? Journal of Banking and Finance, Vol. 50. 383-399. o. https://doi.org/10.1016/j.jbankfin. 2014.02.006.

Glasserman, P.-Young, H. P. [2016]: Contagion in Financial Networks. Journal of Economic Literature, Vol. 54. No. 3. 779-831. o. https://doi.org/10.1257/jel.20151228.

Groote Scha arsberg, M.-Reijnierse, H.-Borm, P. [2013]: On Solving Liability Problems. CentER Discussion Paper, 2013-033. Tilburg University, Tilburg, 1-24. o. https:/doi. org/10.2139/ssrn.2278948.

Habis Helga [2012]: Sztochasztikus csődjátékok - avagy hogyan osszunk szét egy bizonytalan méretü tortát? Közgazdasági Szemle, 59. évf. 12. sz. 1299-1310. o.

Ju, B.-G.-Miyagawa, E.-SAKaI, T. [2007]: Non-manipulable division rules in Claim Problems and Generalizations. Journal of Economic Theory, Vol. 132. No. 1. 1-26. o. https:// doi.org/10.1016/j.jet.2005.08.003.

Kaminski, M. M. [2000]: 'Hydraulic' Rationing. Mathematical Social Sciences, Vol. 40. No. 2. 131-155. o. https://doi.org/10.1016/s0165-4896(99)00045-1.

Lublóy ÁGNes [2005]: Dominóhatás a magyar bankközi piacon. Közgazdasági Szemle, 52. évf. 4. sz. 377-401. o.

Moreno-Ternero, J. D. [2006]: Proportionality and Non-manipulability in Bankruptcy Problems. International Game Theory Review, Vol. 8. 127-139. o. https://doi.org/10.1142/ s0219198906000825.

Moulin, H. [2016]: Entropy, Desegregation, and Proportional Rationing. Journal of Economic Theory, Vol. 162. 1-20. o. https://doi.org/10.1016/j.jet.2015.12.002.

O’Neill, B. [1982]: A Problem of Rights Arbitration from the Talmud. Mathematical Social Sciences, Vol. 2. No. 4. 345-371. o. https://doi.org/10.1016/0165-4896(82)90029-4.

Rogers, L. C. G.-VeraArt, L. A. M. [2013]: Failure and Rescue in an Interbank Network. Management Science, Vol. 59. No. 4. 882-898. o. https://doi.org/10.1287/mnsc.1120.1569.

Schuldenzucker, S.-Seuken, S.-Battiston, S. [2016]: Clearing Payments in Financial Networks with Credit Default Swaps. Working Paper, 1-35. o.

SHIN, H. S. [2008]: Risk and Liquidity in a System Context. Journal of Financial Intermediation, Vol. 17. No. 3. 315-329. o. https://doi.org/10.1016/j.jfi.2008.02.003.

TAsnádi Attila [2002]: On Probabilistic Rationing Methods. Mathematical Social Sciences, Vol. 44. No. 2. 211-221. o. https://doi.org/10.1016/s0165-4896(02)00014-8.

Thomson, W. [2003]: Axiomatic and Game-theoretic Analysis of Bankruptcy and Taxation Problems: A Survey. Mathematical Social Sciences, Vol. 45. 249-297 o. https://doi.org/ 10.1016/s0165-4896(02)00070-7. 
Thomson, W. [2013]: Game-theoretic Analysis of Bankruptcy and Taxation Problems: Recent Advances. International Game Theory Review, Vol. 15. No. 3. 1-14. o. https://doi. org/10.1142/s0219198913400185.

Thomson, W. [2015]: Axiomatic and Game-theoretic Analysis of Bankruptcy and Taxation Problems: An Update. Mathematical Social Sciences, Vol. 74. 41-59. o. https://doi. org/10.1016/j.mathsocsci.2014.09.002.

Thomson, W. [2016]: A new characterization of the proportional rule for claims problems. Economics Letters, Vol. 44. 145. No. C, 255-257. o. https://doi.org/10.1016/j.econlet. 2016.07.009.

Young, H. P. [1988]: Distributive justice in taxation. Journal of Economic Theory, Vol. 44. No. 2. 321-335. o. https://doi.org/10.1016/0022-0531(88)90007-5.

\section{Hely reigazít ás}

A Közgazdasági Szemle előző lapszámában (LXIV. évf. 7-8. sz.) Székffy Klára Vagyoneladás és a tulajdonosi struktúra változása az európai energiaszolgáltató szektorban 2010 és 2016 között című cikkének 797. oldaláról sajnálatos módon kimaradt a További várható eladások az európai energiaszektorban című alfejezet 3. bekezdése:

„Az EdF az atomerőművi biztonságtechnika növekvő terheit, a megvalósulás alatt álló hazai és a kezdés előtt álló angol atomerőművek finanszírozási igényeit részben a 2020-ig tartó, 10 milliárd euró célösszegű vagyoneladás révén kívánja finanszírozni. E terv két nagyobb eladást foglal magában: az olasz földgázszállításban fontos szerepet játszó leányvállalat és a lengyel szénbázisú hőerőművi portfólió elidegenítését. Az EdF 2017 májusában egy, a piacon meghatározó lengyel energiaszolgáltatóval megállapodott üzleti portfóliójának átadásáról. Az olasz Edison eladását nyilvános kibocsátás formájában tervezi. Az EdF fontolgatja az Egyesült Királyságban működő szén- és földgázbázisú erőművei eladását is. Feszített beruházási tervei miatt nem tudja e kapacitásait modernizálni. Ennek hiányában pedig ezek az erőművek nem fognak megfelelni a szigorodó szén-dioxid-kibocsátási normáknak."

A szerzőtől és az olvasóktól elnézést kérünk, a hibát a cikk elektronikus változatában kijavítottuk. 